\title{
EFFECT OF SOME LEVELING METHODS ON EGYPETION CLOVER YIELD
}

\author{
R. A. Werby*
}

ABSTRACT

Field experiments of this work were carried out in a clay soil during the 2014 / 2015 seasons in Arumon, village-Kafrelsheikh Governorate. The aim of this work was to study the effect of some land leveling methods on seeds emergence percentage, For of Egyptian clover yield and net profit. To achieve this goal, the following experiments were used:

1 - The chisel plough at a depth of $15 \mathrm{~cm}$ (one pass) followed by laser land leveling $\left(T_{1}\right)$.

2 - The chisel plough at a depth of $15 \mathrm{~cm}$ (one pass) followed by traditional land leveling $\left(T_{2}\right)$.

3 - The used land with rice residues left on it without leveling $\left(T_{3}\right)$.

The planting was carried out by manual broadcasting (30 kg / Fed) on all experiments.

The main results in this study can be summarized in the following points.

- The maximum seed emergence percentage $62 \%$ was obtained by using chisel plough (one pass) followed by laser land leveling and the minimum grain emergence of $32.8 \%$ was obtained by using unleveled land with rice residues.

- The maximum forage productivity $116.5 \mathrm{Mg} / \mathrm{fed}$ (the four clippings 29.1, 29.8, 32.1 and $25.5 \mathrm{Mg} / \mathrm{fed}$ ) was obtained by using chisel plough (one pass) followed by laser land leveling and the minimum forage productivity was78.2 Mg / fed (from 16.4, 19.8, 22.7 and 19.3 $\mathrm{Mg} / \mathrm{fed}$ ) for mowing by using unleveled land with rice residues.

- The highest net profit (11440 LE / fed ) was obtained with chisel plough (one pass) followed by laser land leveling and the lowest (7790 $L E / f e d$ )was obtained with unleveled land with rice residues.

\footnotetext{
*Assoc. Prof., Agr. Mach. And Power, Fac. of Agr. Eng, Al-Azhar Univ, Cairo.
} 


\section{INTRODUCTION}

lover is one of the major animal feeding crops in Egypt. It is used fresh during winter and spring seasons ( from November to May) , or conditioned as hay or silage to feed animals in summer. It is also the main source of plant protein for animals in Egypt, Imbabi et al. ( 2003) .Clover cultivated area is about 1.908 million feddan yearly ( Ministry of Agriculture and Land Reclamation, 2012). Usually, sowing is directly after harvesting rice as zero tillage. Therefore, before sowing seeds, it is necessary to create a suitable seedbed for good seed germination. Thus, a correct seedbed will ensure the adequate moisture, air quantities and soil bed needed by clover plant. Land leveling saves irrigation water, facilitates field operation, and increases yield Rickman, (2002)

Bahnas (2010) found that the minimum tillage at the precision land leveling slope of $0.02 \%$ achieved higher beet yield of $28.65 \mathrm{Mg} / \mathrm{fed}$ with a sucrose yield of $22.04 \%$, and complemented the higher total dry (14\% moisture content d.b.) clover yield of $17.10 \mathrm{Mg} / \mathrm{fed}$, in five mowings( $2.12,3.32,4.04,4.36$ and $2.87 \mathrm{Mg} / \mathrm{fed}$ ) respectively.

El-Saharigi et al. (1993) found that land leveling using laser grade control equipment showed significant water saving and yield increases over the conventionally leveled land and reduced the average costs of production by 6.3 to $15.4 \%$ for wheat, beans, cotton, and maize. So, the most important factors for proper water management are the slope of furrows and furrow length. El-Hadad (2000) reported that the precision land leveling by laser improved water use efficiency. It increased from 2.7 to $4.7 \mathrm{~kg} / \mathrm{m}^{3}$ of water for wheat.

El Saharigi et al. ( 2001) concluded the highest grain productivity (1.5 $1.95 \mathrm{Mg} /$ fed )was obtained by using straight band sowing by grain drill with straight distributors and laser land leveling and the lowest yield ( $0.966 \mathrm{Mg} /$ fed) was obtained by using manual broadcasting and traditional land leveling. 
Awad et al. (2004) found that the laser leveling increases field irrigation efficiency by $29.3 \%$, saves water by $19-39 \%$, increases maize yield by $3.67 \%$ and consequently increased crop water use efficiency by $18-26 \%$ compared with traditional leveling.

Mc-Clung et al. (1985) found that land leveling using laser controlled equipment increased irrigation efficiency and yield in large level basin. El-Osaman (1988) found that precision land leveling ( controlled with laser equipment) saved $42 \%$ of the irrigation water compared with traditional leveling and increased onion production by $60 \%$.

The objective of the present paper is to study the effect of some leveling methods on seed emergence percentage, clover forage productivity, and net profit.

\section{MATERIALS AND METHODS}

The experiments were carried out in clay soil at Arumon, villageKafrelsheikh Governorate, during 2014 / 2015 seasons.

Field layout: The field layout was $100 \times 42 \mathrm{~m}\left(4200 \mathrm{~m}^{2}\right)$, which was divided into three plots. Each plot has $33.3 \mathrm{~m}$ width and $42 \mathrm{~m}$ length.

Soil properties: The experiments were carried out in clay soil texture. The mechanical analysis and soil properties are given in Table(1).

Table 1 : The soil mechanical analysis and son properties.

\begin{tabular}{|c|c|c|c|c|c|}
\hline $\begin{array}{c}\text { Depth of } \\
\text { sample }\end{array}$ & $\begin{array}{c}\text { Clay } \\
\%\end{array}$ & $\begin{array}{c}\text { Silt } \\
\%\end{array}$ & $\begin{array}{c}\text { Sand } \\
\%\end{array}$ & $\begin{array}{c}\text { MC, } \\
\%\end{array}$ & $\begin{array}{c}\text { Bulk density, } \\
\mathrm{g} / \mathrm{cm}^{3}\end{array}$ \\
\hline $0-15$ & 49 & 29 & 22 & 21.75 & 1.35 \\
\hline
\end{tabular}

Field experiments: To achieve this goal the following treatments were used and tested:

1- Chisel ploughing at depth $15 \mathrm{~cm}$ (one pass) followed by laser land leveling $\left(\mathrm{T}_{1}\right)$. 
2- Chisel ploughing at depth $15 \mathrm{~cm}$ (one pass) followed by traditional land leveling $\left(\mathrm{T}_{2}\right)$.

3- Direct using on soil with rice residues $\left(T_{3}\right)$.

Sowing method and seed variety: sowing was by manual broadcasting in all experiments at seed rate of $30 \mathrm{~kg} / \mathrm{Fed}$ (seeds mass of $4.16 \mathrm{~g}$ for 1000 seeds ) of the variety of Meskawy.

\section{The emergence percentage \%:}

$$
=\text { Seed emergence }\left(\text { N. } / \mathrm{m}^{2}\right) / \text { seed rate }\left(\mathrm{N} . / \mathrm{m}^{2}\right)
$$

The emergence of clover plant was evaluated by taking 12 samples $\left(1 \mathrm{~m}^{2}\right)$ randomly selected from each plot as the number of clover stalks.

The productivity : The clover productivity was evaluated by taking 12 samples $\left(1 \mathrm{~m}^{2}\right)$ randomly selected from each plot. The plants were mowed by hand sickle then weighed for all mowings $\left(1^{\text {st }}, 2^{\text {nd }}, 3^{\text {rd }}\right.$, and $\left.4^{\text {th }}\right)$.

Productivity determination $(\mathrm{Mg} / \mathrm{fed})=(\mathrm{W}$ x 4200) $/ 1000$

Where;

$\mathrm{W}$ : mass of mowed clover, $\mathrm{kg} / \mathrm{m}^{2}$

\section{Estimating costs:}

Estimating costs included the rent values of the machines and manual labor broadcasting.

Total cost $=$ Labor wages $($ L.E $/$ fed $)+$ tillage wages $($ L.E $/$ fed $)+$ leveling wages( L.E / fed ) .

Clover productivity price $(\mathrm{LE} / \mathrm{fed})=$ clover price $(100 \mathrm{LE} / \mathrm{Mg}) \mathrm{x}$ clover productivity ( $\mathrm{Mg} / \mathrm{fed})$.

Net profit: Net profit $(\mathrm{LE} / \mathrm{fed})=$ clover productivity price $(\mathrm{LE} / \mathrm{fed})-$ total productivity costs (LE/fed). 
Some physical properties of clover : a square wooden from with dimensions of $20 \times 20 \mathrm{~cm}$ was used to remark an area during the experiment. The determination was repeated on twenty five random for each mowing to get the mean shown in table (2).

Table (2): Some physical properties of clover stalks (in four mows)

\begin{tabular}{|c|c|c|c|c|c|c|c|c|c|c|c|c|}
\hline & \multicolumn{12}{|c|}{ Land leveling methods } \\
\hline Parameters & \multicolumn{4}{|c|}{$\begin{array}{c}\text { Chisel plough and laser } \\
\text { leveling }\end{array}$} & \multicolumn{4}{|c|}{$\begin{array}{l}\text { Chisel plough and } \\
\text { traditional leveling }\end{array}$} & \multicolumn{4}{|c|}{$\begin{array}{l}\text { unleveled land with rice } \\
\text { residues }\end{array}$} \\
\hline Mowing & 1 & 2 & 3 & 4 & 1 & 2 & 3 & 4 & 1 & 2 & 3 & 4 \\
\hline Length (L) $\mathrm{cm}$ & 62 & 63 & 64.1 & 58 & 61 & 63 & 63.5 & 54 & 59.6 & 60 & 60.3 & 55 \\
\hline $\begin{array}{l}\text { Outside } \\
\text { diameter }\left(D_{\text {out }}\right) \\
\text { mm }\end{array}$ & 3.3 & 3.6 & 3.7 & 3.6 & 3.3 & 3.7 & 3.7 & 3.1 & 3.4 & 3.8 & 3.9 & 3.4 \\
\hline $\begin{array}{l}\text { Inside } \\
\text { diameter }\left(D_{\text {in }}\right) \\
m m\end{array}$ & 2.2 & 2.2 & 2.6 & 2.3 & 2.2 & 2.1 & 2.6 & 2.3 & 2.1 & 2.3 & 2.7 & 2.3 \\
\hline $\operatorname{Mass}(\mathrm{M}) \mathrm{g}$ & 6.7 & 5.9 & 4.7 & 3.9 & 6.9 & 6 & 4.6 & 4 & 7.1 & 6.2 & 4.5 & 4 \\
\hline $\begin{array}{lr}\text { Intensity } & \text { of } \\
\text { stalk as } & \left(\mathrm{N}_{\mathrm{s}}\right) \\
\text { stalk } / \mathrm{m}^{2} & \end{array}$ & 1034 & 1204 & 1625 & 1557 & 805 & 1076 & 1464 & 1386 & 550 & 762 & 1200 & 1151 \\
\hline $\begin{array}{l}\text { Moisture } \\
\text { content(m.c) } \\
\%\end{array}$ & 85 & 77 & 70 & 67 & 85 & 77 & 70 & 67 & 85 & 77 & 70 & 67 \\
\hline
\end{tabular}

\section{RRSULTS AND DISCUSSION}

\section{1- Effect of leveling methods on clover seeds emergence percentage .}

Figure (1) show the emergence percentage from different leveling methods.

Data show that the maximum clover seed emergence percentage (62\%) was obtained by using chisel plough (one pass) and laser land leveling. Minimum clover seed emergence percentage ( $32.8 \%$ ) was obtained by no tillage and no land leveling ( soil with rice residues). This may be due to the roots of rice left after harvesting obstructing the clover seed growing and increasing seed losses. 
The sequence of the different methods according to the germination percent was found to be in the descending order:

$$
(\mathrm{T} 1(62 \%)>\mathrm{T} 2(48 \%)>\mathrm{T} 3(32.8 \%)
$$

\section{2- Effect of leveling methods on clover forage productivity.}

Figure (2) show the forage productivity of clover crop at different leveling methods.

Data show that the maximum productivity of clover crop was (116.5 Mg / fed )was obtained by using chisel plough (one pass) and land leveling laser and minimum forage productivity of clover crop ( $78.2 \mathrm{Mg} / \mathrm{fed}$ ) was obtained by no tillage and no land leveling ( field therein of remain Rice). This may be due to decreasing the number of plants emerge in first mowing and increasing seed losses in remaining rice straw.

The sequence of the different methods according to the germination percent was found to be in the descending order:

$$
(\mathrm{T} 1(116.5 \mathrm{Mg} / \mathrm{fed})>\mathrm{T} 2(101.9 \mathrm{Mg} / \mathrm{fed})>\mathrm{T} 3(78.2 \mathrm{Mg} / \mathrm{fed})
$$

\section{3 - Estimating costs.}

The operating cost for tillage, land leveling and manual broadcasting are shown in Fig (3) .

The minimum operating cost of $30 \mathrm{LE} /$ fed was obtained with no tillage and no leveling and the maximum operating cost of $210 \mathrm{LE} / \mathrm{fed}$ was obtained with chisel plough (one pass), followed by laser land leveling.

Table 3 and fig. 3 show that the highest net profit ( $11440 \mathrm{~L} /$ fed )was obtained with using chisel plough and laser land leveling and the lowest (7790 L/fed )was obtained with using no chisel plough and no land leveling.

\section{CONCLUSIONS}

Studies show that chisel plough (one pass) on depth $15 \mathrm{~cm}$ with laser land leveling can increase crop yields percentage $(33 \%)$. It is recommended to use chisel plough (one pass) on depth $15 \mathrm{~cm}$ with laser land leveler to give highest productivity. 

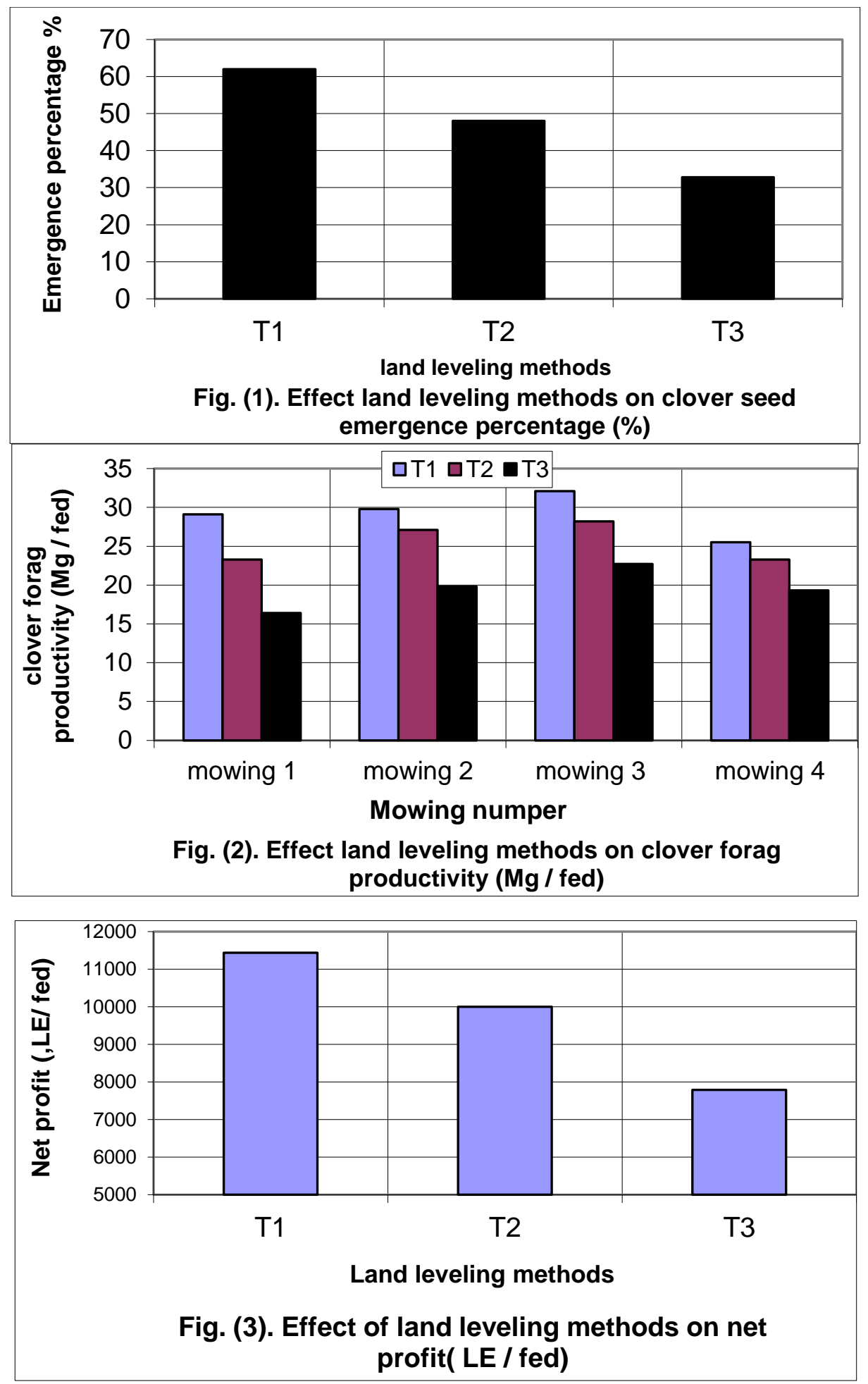


\section{REFERENCES}

Awad M. A. M. R., Goman., (2004) Precision leveling effects on strip and furrow irrigations for maize. Misr J, Ag. Eng., 21 (1): 87-102.

Bahuas, O. T, (2010) Effect of minimum tillage on conservation of precise leveled soil to produce some winter crops after rice. Misr J, Agr. Eng., 27(4): 1125-1139.

El-Haddad, Z. A, (2000) To whomt my concern agricultural modernization is a must for future several, EL-Ahram pub No 1689 / 2002 p 37.

El-Sahrigi, A. F., M . EL. Gindy • (1993): on farm improved irrigation management using laser technology, Farm mechanization and irrigation systems Agri. Eng. Res. Inst., Agri. Res. Center, Ministry of Agriculture and Land reclamation Egypt.

El-Sahrigi, A. F., A. E., Sayed, and G. H., Yehia,(2001): Effect of some planting and land leveling systems on barely crop productivity, gth conf of Misr. Soc. Of Ag. Eng.: 9-11 sept, : 133-146.

Imbabi, A. T.; B. S. Azzam, and m. Z. Abdou, (2003) Evaluation of using small reel mower for cutting Egyptian clover.Misr. J. Ag. Eng. $16(3) ; 21-33$.

Ministry of Agriculture and Land Reclamation Economic Affalrs Sector (EAS) (2012). Study of the indicators agricultural statistics. Pi .86 .

Mc-Clung J. A., S. Shepley., M. Ismail and M. N. Seif El-Yazal (1985) Mechanical and Economic study of land leveling in Middle Egypt. Agr. Mec Proj Paper work No. 21 .Ministry of Agric. Egypt. 
Osman H. E., (1988) Effect of different methods of land leveling and improved surface irrigation method and vegetable crop. M.Sc Thesis. Moshtohor Fac. of Agr. Univ, of Zagazig Egypt, ; 56p.

Rickman, J.F. ( 2002 ). Manual for laser land leveling, Rice - wheat Consortium Technical Bulletin Series 5 . New Delhi-12, India: Rice wheat Consortium for the Indo-Gangetic Plains. Pp.24.

\section{الملخص العربي}

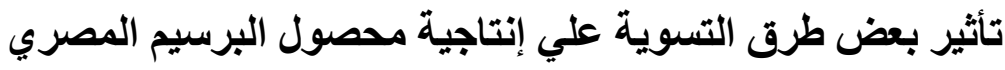

$$
\text { د / رأفت علي أحمد وربي }
$$

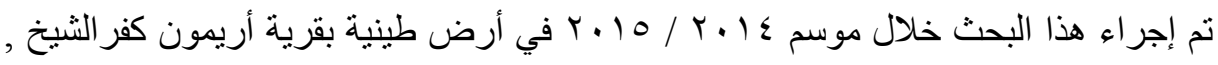

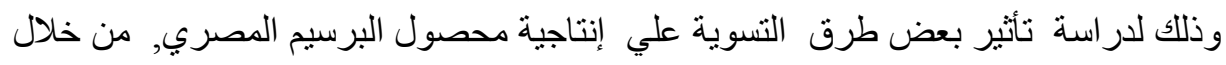

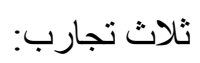

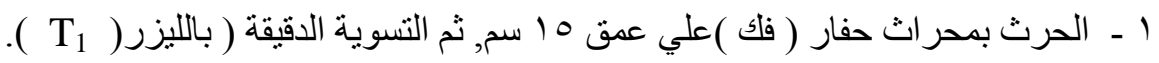

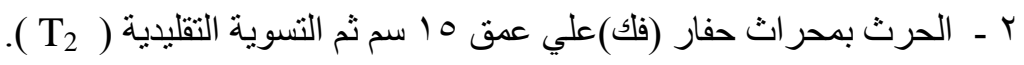
r - استخدام أرض بها بقايا محصول سابق( أرز) بدون تسوية ( T3 ) ).

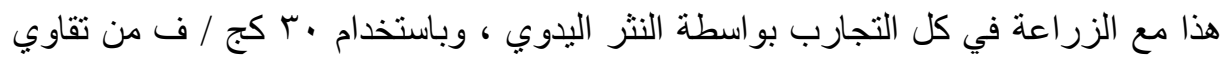

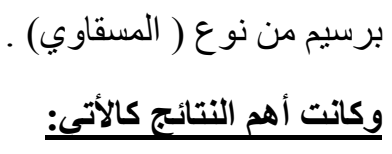

1 - نسبة الإنبات : وجد أن اعلي نسبة للإنبات كانت r7 \% مع استخدام الحرث بمحراث حفار (فلك) ثم التسوية الدقيقة بالليزر, وكانت اقل نسبة إنبات م, بr \% مع استخدام أرض بها بقايا (محصول سابق أرز بدون حرث وبدون تسوية ).

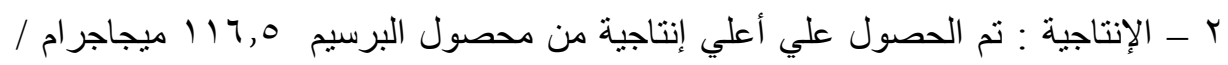

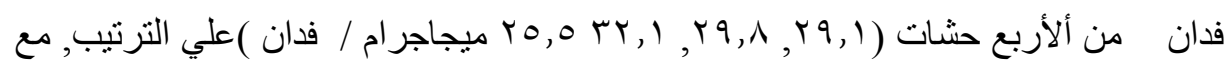

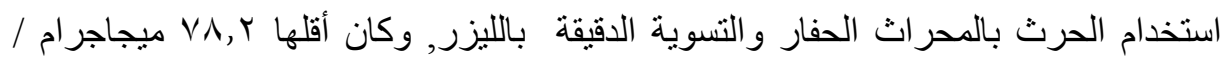

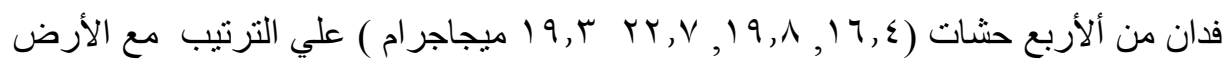
التي بها بقايا محصول سابق (بدون حرث وبدون تسوية) .

أستاذ مساعد ـ قسم القوي والآلات الزراعية ـكلية الهندسة الزراعية ـجامعة الأزهر- القاهرة. 
r - التكاليف: وجد أن اقل تكاليف تشغيل (•r جنية/فدان )كانت عند استخدام أرض بها بقايا

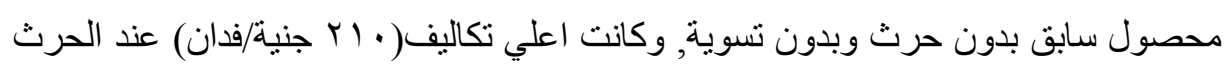

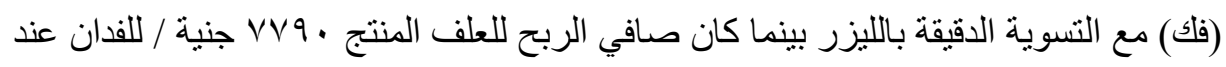

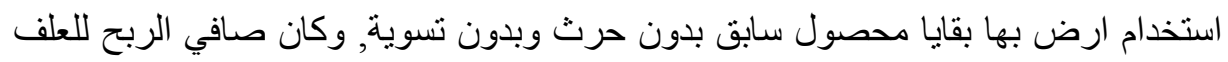

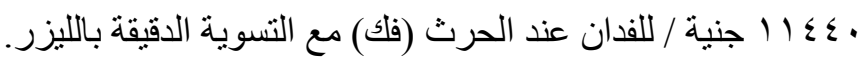
ويوصي باستخدام الحرث (فك) و التسوية الدقيقة بالليزر لزر اعة البرسيم المصري للحصول

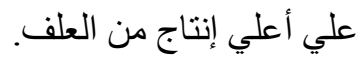

